\title{
Avaliação in vitro de clorexidina, amônia quaternária e ácido peracético frente a amostras de Salmonella Heidelberg isoladas de abatedouro avícola em 2005 e $2009^{1}$
}

\author{
Fernanda Lúcia Colla ${ }^{2}$, Laura B. Rodrigues ${ }^{2}$, Elci Lotar Dickel ${ }^{2}$, Anderlise Borsoi ${ }^{3}$, \\ Vladimir Pinheiro do Nascimento ${ }^{4}$ e Luciana Ruschel dos Santos ${ }^{2 * *}$
}

\begin{abstract}
Colla F.L., Rodrigues L.B., Dickel E.L., Borsoi A., Nascimento V.P. \& Santos L.R. 2012. [In vitro evaluation of chlorhexidine, quaternary ammonium and peracetic acid against Salmonella Heidelberg isolated from poultry slaughterhouse in 2005 and 2009.] Avaliação in vitro de clorexidina, amônia quaternária e ácido peracético frente a amostras de Salmonella Heidelberg isoladas de abatedouro avícola em 2005 e 2009. Pesquisa Veterinária Brasileira 32(4):289-292. Curso de Medicina Veterinária, Faculdade de Agronomia e Medicina Veterinária, Universidade de Passo Fundo, Campus I, BR 285, Passo Fundo, RS 99052-900, Brazil. E-mail: luruschel@upf.br

The objective of this investigation was to evaluate the in vitro sensibility of Salmonella Heidelberg to three commercially available disinfectants used for sanitization in poultry slaughterhouses. A total of $20 \mathrm{~S}$. Heidelberg were tested (14 isolated in 2005 and six in $2009)$, and as active ingredients were used chlorhexidine (0.5\%), quaternary ammonium $(0.5 \%)$ and peracetic acid (1\%) at contact intervals of 5, 10, 15 e 20 minutes. All isolates were found to be sensitive to peracetic acid at four specific contact intervals. One hundred percent of $S$. Heidelberg isolated in 2005 was found to be sensitive to quaternary ammonium, while $33 \%$ of 2009 isolates were resistant at a 5-minute contact interval and $16.6 \%$ at 10 -minutes. With respect to chlorhexidine, $25 \%$ of the 2005 isolates were resistant at a 5-minute contact interval, $33 \%$ of the 2009 isolates were resistant with the same time, and $17 \%$ at a 10 -minute contact interval. It can be concluded that the highest disinfectant activity in vitro was found to be with peracetic acid for $S$. Heidelberg isolates in 2005 and 2009, whereas chlorhexidine and quaternary ammonium had a reduced action against 2009 isolates, indicating the progression of bacterial resistance against these sanitizers and the need for periodic evaluation and rotation of active principles for sanitization.
\end{abstract}

INDEX TERMS: Sanitizers, Salmonella Heidelberg, poultry slaughterhouse.

RESUMO.- Objetivou-se avaliar a ação de três princípios ativos rotineiramente utilizados na higienização de abatedouros avícolas frente a amostras de Salmonella Heidelberg isoladas em diferentes pontos da tecnologia de abate

\footnotetext{
${ }^{1}$ Recebido em 13 de setembro de 2011.

Aceito para publicação em 11 de novembro de 2011

${ }^{2}$ Curso de Medicina Veterinária, Faculdade de Agronomia e Medicina Veterinária, Universidade de Passo Fundo (UPF), BR 285, Bairro São José, Passo Fundo, RS 99052-900, Brasil. *Bolsista PIBIC CNPq. **Autor para correspondência: luruschel@upf.br

${ }^{3}$ Faculdade de Medicina Veterinária, Universidade Tuiuti do Paraná, Rua Sydnei Rangel dos Santos 238, Santo Inácio, PR 82010-330, Brasil.

${ }^{4}$ Centro de Diagnóstico e Pesquisa em Patologia Aviária, Faculdade de Veterinária, Universidade Federal do Rio Grande do Sul (UFRGS), Av. Bento Gonçalves 8824, Porto Alegre, RS 91540-000, Brasil.
}

de um mesmo frigorífico. Foram testadas 20 amostras de $S$. Heidelberg (14 isoladas em 2005 e seis em 2009) frente a clorexidina $(0,5 \%)$, amônia quaternária $(0,5 \%)$ e ácido peracético (1\%) nos tempos de contato de 5, 10, 15 e 20 minutos. Todas as amostras foram sensíveis ao ácido peracético $1 \%$ em todos os tempos testados. Observou-se que $100 \%$ das amostras isoladas em 2005 foram sensíveis a amônia quaternária enquanto que as isoladas em 2009 apresentaram 33\% de resistência com 5 minutos de contato e 16,6\% com 10 minutos de contato. Com relação à clorexidina, $25 \%$ dos isolados em 2005 mostraram-se resistentes após 5 minutos de contato enquanto que $33 \%$ das amostras isoladas em 2009 foram resistentes neste tempo e $17 \%$ no tempo de 10 minutos de contato. Pode-se concluir que o ácido peracético teve ação in vitro sobre as amostras isola- 
das em 2005 e 2009, enquanto que a clorexidina e a amônia quaternária tiveram sua ação reduzida frente às amostras de 2009, indicando a progressão da resistência bacteriana frente a estes sanitizantes e a necessidade de testes periódicos e rotação de princípios ativos nos programas de higienização dos frigoríficos.

TERMOS DE INDEXAÇ̃̃O: Sanitizantes, Salmonella Heidelberg, abatedouro avícola.

\section{INTRODUÇÃO}

A carne de aves e seus derivados são considerados os principais alimentos envolvidos em surtos de infecções por Salmonella em decorrência do preparo inadequado e da contaminação cruzada. Na prevenção da ocorrência ou na interrupção da evolução de enfermidades infecto-transmissíveis comuns aos animais e aos seres humanos, o uso de um desinfetante capaz de agir sobre o agente causal quando em vida livre, no ambiente, exerce grande importância. No entanto, a resistência microbiana, intrínseca ou adquirida, pode apresentar-se como um limitante no uso deste instrumento sanitário (Borowsky et al. 2006). As salmonelas paratíficas são tipicamente associadas a doenças não sintomáticas, mas com diferentes padrões de colonização no trato intestinal das aves. As boas práticas de fabricação nas plantas de abate podem reduzir a contaminação do produto final, sendo essencial o controle de pontos críticos ao longo de toda a cadeia de produção (Bailey et al. 1991).

0 procedimento de higienização nos matadouros de aves consiste fundamentalmente no uso de água quente, detergentes e sanificantes. Embora os detergentes diminuam a carga bacteriana das superfícies, o objetivo principal do seu uso é a remoção de resíduos orgânicos e minerais. A sanitização, última etapa do procedimento de higienização, visa reduzir microrganismos alteradores e eliminar patogênicos até níveis seguros, de modo a obter um produto de boa qualidade higiênico-sanitária (Moraes et al. 1997). $\mathrm{Na}$ indústria de carnes e derivados, a limpeza e sanitização é prática de extrema importância no sentido de evitar contaminação dos alimentos, que levam à perda das suas qualidades organolépticas e nutricionais, bem como a sua degradação, que pode ocasionar enfermidades de maior ou menor gravidade ao homem (Pardi et al. 1995).

Este trabalho objetivou avaliar a ação in vitro de três sanitizantes comerciais frente a amostras de Salmonella Heidelberg isoladas em um mesmo abatedouro de aves em diferentes períodos (2005 e 2009) a fim de se observar a resistência ou sensibilidade destes isolados frente a produtos de uso rotineiro nos programas de higienização dos frigoríficos.

\section{MATERIAL E MÉTODOS}

Foram avaliadas 20 amotras de Salmonella Heidelberg (SH) isoladas do mesmo abatedouro em 2005 (14 amostras, sendo as SH 2, $4,5,6,7,8,11,12$ e 14 isoladas de carcaças antes do chiller; SH 3, 9,10 e 13 de carcaças depois do chiller e SH 15 e 16 de suabes de cloaca) e em 2009 (seis amostras) isoladas de pontos críticos de abatedouro de aves, sendo quatro SH provenientes de aves após a depenagem e duas SH isoladas de amostras de água do chiller. Utilizou-se metodologia adaptada para quantificação de Salmonella
(Desmidit et al. 1998, Dufrenne et al. 2001), como segue: pools de swabs de cloaca foram colocados em $50 \mathrm{~mL}$ de água peptonada $1 \%$ (AP $1 \%$ ) e incubados a $37^{\circ} \mathrm{C}$ por 12 horas. Nas análises de água inoculou-se $100 \mathrm{~mL}$ da amostra em $50 \mathrm{~mL}$ de AP $1 \%$ com concentração tripla e incubou-se por 12 horas a $37^{\circ} \mathrm{C}$. Os frangos e carcaças foram acondicionados em sacos estéreis com capacidade para $4000 \mathrm{~mL}$, adicionados $150 \mathrm{~mL}$ de AP $1 \%$, agitados manualmente por um minuto e o caldo de rinsagem incubado por 12 horas a 37ํㅡ. Após incubação foram feitas diluições decimais da AP 1\% em caldo Rapapport Vassiliadis (RV), sendo inoculados $1 \mathrm{~mL}$ de AP $1 \%$ em $9 \mathrm{~mL}$ de caldo RV até a diluição $10^{-3}$ e os caldos RV incubados por $24 \mathrm{~h}$ a $41^{\circ} \mathrm{C}$ em banho-maria, com agitação. Após este período foram semeados com alça de Drigalski $100 \mu \mathrm{L}$ de cada diluição de caldo RV em Agar Rambach e Agar XLD, em duplicata, e as placas incubadas a $37^{\circ} \mathrm{C}$ por 24 horas. Colônias compatíveis com Salmonella foram reisoladas em Agar Rambach, incubadas a $37^{\circ} \mathrm{C} / 24$ horas e submetidas a provas bioquímicas (inoculação em TSI, LIA, SIM e caldo uréia) e Agar nutriente para sorologia com anti-soro polivalente 0 para Salmonella (Difcoß). A identificação final das salmonelas foi realizada por Reação em Cadeia pela Polimerase (PCR, Premi®Test Salmonella DSM).

Para os testes de eficácia de desinfetantes as amostras foram testadas frente a clorexidina $0,5 \%$, amônia quaternária amônio $0,5 \%$ e ácido peracético $1 \%$. A avaliação da atividade antibacteriana foi realizada pelo método de diluição com teste de suspensão (Brasil 2003). As bactérias foram inoculados em caldo BHI e incubadas por 18 horas a $37^{\circ} \mathrm{C}$ para obtenção de fase estacionária. Em tubos estéreis colocou-se $9 \mathrm{~mL}$ do desinfetante a ser avaliado, $1 \mathrm{~mL}$ de leite integral UHT (Ultra Higth Temperature) e $100 \mu \mathrm{L}$ da cultura teste. Utilizou-se os tempos de contato de 5,10,15 e 20 minutos e repicou-se uma alíquota de $10 \mu \mathrm{L}$ para tubos com $5 \mathrm{ml}$ de BHI (Brain Heart Infusion). Após 96 horas de incubação a $37^{\circ} \mathrm{C}$, considerou-se as bactérias resistentes (R) quando o meio de cultura apresentou turbidez e sensíveis (S) na ausência de turbidez (Beltrame 2009).

\section{RESULTADOS}

Todas as amostras isoladas em 2005 mostraram-se susceptíveis a amônia quaternária $0,5 \%$, enquanto que as amostras isoladas em 2009 apresentaram resistência de $33,3 \%$ com 5 minutos de contato e de $16,6 \%$ com $10 \mathrm{mi}-$ nutos de contato. Vinte e cinco por cento das amostras de 2005 mostraram-se resistentes a clorexidina $0,5 \%$ com 5 minutos de contato e, considerando as amostras de 2009, observou-se resistência de 33,3\% com 5 minutos de contato e $17 \%$ com 10 minutos. Todas as amostras foram sensíveis ao ácido peracético 1\%. Das nove amostras isoladas em 2005 de carcaças de frango antes do chiller, três delas apresentaram resistência à ação da clorexidina. Quando testadas frente a amônia quaternária e ácido peracético, apresentaram $100 \%$ de sensibilidade. As quatro amostras isoladas de carcaças de frango após o chiller foram sensíveis ao ácido peracético e à amônia quaternária e apenas uma das amostras foi resistente à clorexidina. As amostras de Salmonella Heidelberg isoladas de swabs cloacais foram sensíveis a todos os sanitizantes avaliados. Dentre as amostras isoladas em 2009 após a depenagem, 50\% foram resistentes a ação da amônia quaternária $0,5 \%$ e clorexidina $0,5 \%$, sendo que apenas uma das amostras foi resistente aos dois sanitizantes. As amostras isoladas neste mesmo ano da água do chiller foram sensíveis a todos os sanitizantes testados. 


\section{DISCUSSÃO}

0 ácido peracético possui excelente ação sanitizante e esporicida. Neste estudo apresentou $100 \%$ de ação frente a todas as amostras nos quatro tempos de contato. A boa ação deste produto leva a duas inferências: (1) o teste in vitro é um indicativo da ação do produto, devendo-se levar em consideração a importância da higienização prévia das superfícies dos frigoríficos para melhor atuação deste princípio ativo; (2) mesmo produtos com boa ação devem sofrer alternância com outros produtos eficazes visando a não progressão de resistência bacteriana.

A clorexidina foi introduzida há muitos anos como anti-séptico de amplo espectro. Neste estudo, os resultados indicaram um processo de desenvolvimento de resistência a este sanitizante, que apresentou um índice de resistência de $25 \%$ entre as amostras de SH isoladas em 2005 e uma progressão para 33,3\% em 2009. Beltrame (2009), observou um incremento da eficiência da clorexidina quando a temperatura do diluente é elevada de $10^{\circ} \mathrm{C}$ para $45^{\circ} \mathrm{C}$, sendo que o sanitizante mostrou-se eficaz mesmo na concentração de 0,2\% em 18 minutos de tempo de contato.

Os compostos de amônia quaternária são detergentes catiônicos sintéticos que possuem atividade antimicrobiana, boa estabilidade, solubilidade em água e toxicidade relativamente baixa (Pelczar et al. 1980). A amônia quaternária é eficiente em baixas concentrações frente a bactérias, bolores, leveduras e vírus (Frasier 1993). Sua ação bactericida é atribuída à inativação de enzimas responsáveis pelos processos de transformação de energia, à desnaturação de proteínas celulares e à ruptura da membrana celular (Romão 1996). Borowsky et al. (2006) ao confrontar amostras de Salmonella Typhimurium a duas concentrações diferentes, $0,1 \mathrm{mg} . \mathrm{L}^{-1}$ (concentração recomendada) e $0,05 \mathrm{mg} \mathrm{L-}$ -1 (subconcentração) de amônia quaternária observou eficiência de $100 \%$ em ambas as concentrações, com tempo de contato de 5 minutos, diferentemente do que ocorreu neste estudo onde a amônia quaternária $0,5 \%$ mostrou eficácia de $100 \%$ somente com tempos de contato superiores aos 10 minutos.

A resistência microbiana à amônia quaternária é um problema potencial em diferentes áreas da indústria de alimentos (Sundheim et al. 1998). Neste estudo este sanitizante apresentou eficácia de $100 \%$ sobre as SH isoladas em 2005. Porém, 33,3\% das SH isoladas em 2009 mostraramse resistentes após 5 minutos de contato. Beltrame (2009) verificou a eficácia de $100 \%$ da amônia quaternária $0,2 \%$, com tempo de contato de 18 minutos, enquanto concentrações superiores mostraram-se eficazes com o tempo de contato de apenas dois minutos. Deve-se considerar que, na rotina de higienização dos abatedouros de aves, o tempo para ação do sanitizante pode ser inferior a cinco minutos, reforçando a importância do sanitizante utilizado ter ação sobre as bactérias deste ambiente em um período reduzido de tempo.

Em um estudo realizado por Sander et al. (2002), 17 amostras dos gêneros Staphylococcus, Enterococcus, Salmonella, Pseudomonas, Proteus, Escherichia e Pasteurella, isoladas em ambiente de avicultura foram confrontadas com três grupos de desinfetantes: compostos fenólicos, quater- nário de amônio e peróxido de hidrogênio. No caso da Salmonella sp., os desinfetantes do grupo dos fenóis inibiram a maioria das amostras, enquanto que o grupo do quaternário de amônio foi incapaz de promover a inativação das mesmas amostras, o que difere do resultado encontrado neste estudo, no qual o sanitizante com amônia quaternária mostrou ser ativo.

O estudo de Beltrame (2009) revelou que o melhor desempenho frente à Salmonella Choleraesuis foi alcançado com a utilização de ácido peracético a $10^{\circ} \mathrm{C}$. Como segunda opção o autor cita o quaternário de amônio, que apresentou resultados semelhantes em todas as temperaturas testadas e a clorexidina a $45^{\circ} \mathrm{C}$. No presente estudo, quando testados frente a Salmonella Heidelberg, estes sanitizantes apresentaram resultados semelhantes, sendo o ácido peracético o sanitizante de maior eficácia, seguido pela amônia quaternária e a clorhexidina.

Deve-se também considerar que as diluições de uso dos sanitizantes necessitam atender as especificações dos fabricantes e à legislação vigente, particularmente no que se refere a sub dosagens, que podem contribuir para a progressão da resistência bacteriana, e o excesso de produto, que embora menos frequente na rotina de sanitização, pode trazer problemas sanitários e impedimentos de comercialização.

\section{CONCLUSÕES}

De acordo com os resultados obtidos, o ácido peracético teve ação in vitro sobre as amostras isoladas em 2005 e 2009, enquanto que a clorexidina e a amônia quaternária tiveram sua ação reduzida frente às amostras de 2009, indicando a progressão da resistência bacteriana frente a estes sanitizantes e a necessidade de testes periódicos e alternância de princípios ativos nos programas de higienização dos frigoríficos.

O aumento da resistência de Salmonella Heidelberg serve de alerta para a progressão da resistência bacteriana aos sanitizantes usados em abatedouros avícolas e para a necessidade de se documentar e inibir esta progressão.

\section{REFERÊNCIAS}

Bailey J.S., Cox A.C. \& Blankenship L.C. 1991. A comparison of an enzime imunoassay, DNA hibridization, antibody immobilization, and conventional methods for recovery of naturally occurring Salmonellae from processed broiler carcasses. J. Food Protection 54:354-356.

Beltrame C.A. 2009. Avaliação da eficiência de sanitizantes utilizados pelas indústrias de alimentos. Dissertação de Mestrado em Engenharia de Alimentos, Departamento de Ciências Agrárias, Universidade Regional Integrada do Alto Uruguai e das Missões, Erechim, RS. 78p.

Borowsky L.M., Bessa M.C., Cardoso M.I. \& Avancini C.A.M. 2006. Sensibilidade e resistência de amostras de Salmonella typhimurium isoladas de suínos abatidos no Rio Grande do Sul/Brasil frente aos desinfetantes químicos quaternário de amônio e iodofor. Ciência Rural 36:1474-1479.

Brasil 2003. Instrução Normativa no 62 de 26 de agosto de 2003. Oficializar os métodos analíticos oficiais para análises microbiológicas para controle de produtos de origem animal e águas. Secretária de Defesa Agropecuária, MAPA. Diário Oficial da República Federativa do Brasil, Brasília, Seção 1, p.14, 18 de setembro de 2003.

Desmidt M., Ducatelle R. \& Haesebrouck F. 1998. Serological and bacteriological observations on experimental infection with Salmonella hadar in chickens. Veterinary Microbiology 60:259-269. 
Dufrenne J., Ritmeester W. \& Van Asch 2001. Quantification of the contamination of chicken and chicken products in The Netherlands with Salmonella and Campylobacter. J. Food Protection 64:538-541.

Frasier M.C. 1993. Microbiologia de los alimentos. Acribia, Zaragoza. 681p.

Moraes M.S.V., Andrade N.J., Chaves J.B.P., Passos F.J.V. \& Gomide L.A.M. 1997. Isolament of aerobic mesofilic and thermofilic spores in equipaments of poultry slaughter and their resistance against the chemists disinfectants. Ciênc. Tecnol. Aliment.17:325-329.

Pardi M.C., Santos I.F., Souza E.R. \& Pardi H.S. 1995. Ciência, Higiene e Tecnologia da Carne: riscos microbiológicos da carne. Vol.1. UFG, Goiânia, p.294-308.
Pelczar M. 1980. Microbiologia. Vol.1. McGraw-Hill do Brasil, São Paulo.

Romão C.M.C.A. 1996. Desinfecção e esterilização química, p.133-162. In: Teixeira P. (Ed.), Biossegurança: uma abordagem multidisciplinar. Fiocruz, Rio de Janeiro.

Sander J.E., Hofacre C.L., Cheng I.H. \& Wyatt R.D. 2002. Investigation of resistance of bacteria from commercial poultry sources to commercial disinfectants. Avian Dis. 46:997-1000.

Sundheim S., Langsrud E.H. \& Holck A.L. 1998. Bacterial resistance to disinfectants containing quaternary ammonium compounds. I. Biodeterioration and Biodegradation 41:235-239. 